\title{
Perception of Employees Regarding Participation in Decision Making and Problem Solving: A study On Different Branches of Banks in Dhaka City.
}

\author{
Md. Shariful Alam Khandakar ${ }^{1}$ \\ Khadija Huq $^{2 *}$ \\ Sarmin Sultana ${ }^{3}$ \\ ${ }^{1}$ Assistant Professor, Department of Hospitality \& Tourism, University of Dhaka \\ ${ }^{* 2}$ Counselors, Faith Overseas LTD \\ ${ }^{3}$ Lecturer, Stamford University Bangladesh
}

This journal is licensed under a Creative Commons Attribution-NonCommercial 4.0 International License (CC-BY-NC).

Articles can be read and shared for noncommercial purposes under the following conditions:

- BY: Attribution must be given to the original source (Attribution)

- NC: Works may not be used for commercial purposes (Noncommercial)

This license lets others remix, tweak, and build upon your work non-commercially, and although their new works must also acknowledge you and be non-commercial, they don't have to license their derivative works on the same terms.

License Deed Link: http://creativecommons.org/licenses/by-nc/4.0/

Legal Code Link: http://creativecommons.org/licenses/by-nc/4.0/legalcode

$A B C$ Research Alert uses the CC BY-NC to protect the author's work from misuse.

\begin{abstract}
Banking sector is one of the most raising sectors in Bangladesh. This sector is facing competitive pressures due to the rapid changes of market conditions. Participative Decision-making and problem solving is therefore very crucial to the fortunes of any organization as it is through the successful implementation of policy decisions that the goals and objectives of an organization. Employees in the banking sector of Bangladesh perceived that participative decision making improve the organizational performance. They argued that employees are the fuel that runs the engine of the organization and it is believed that their non-involvement in the decision-making process creates tensions between management and staff. This study, therefore, sought to determine the perception of employees' regarding participative decision making. They provided the opinion that management think decision-making as a management tool and its implementation in organizations by determining low employee. Lack of participative decision is the main cause of poor implementation of decisions. In order to achieve the objective of the study an interview was conducted on 57 employees of different private, public and commercial banks of Dhaka city. The findings of the study suggested that employee participation and involvement in decision-making contributes to effective decision implementation and also creates an enabling environment for creativity and growth. If employees see themselves as stakeholders and owners of the decision making and problem solving then implementation of decision will be very smooth. The study was also revealed that when employees see themselves as not being part of the decision-making process, they become discontented and apathetic which is likely to adversely affect organizational performance. Moreover, the study attempt to find out the relationship between participative decision making and organizational commitment.
\end{abstract}

Keywords

Perception, employee participation, decision making, Problem solving.

\section{INTRODUCTION}

Perception is the process by which we can sense or interprets about the world or environment. It differs from person to person and group to group. In general sense, decision making is the process of selecting the best alternative from among the alternatives. In broader sense, 
decision making is the process of recognizing and defining the nature of a decision situation, identifying alternatives, choosing the best alternative and putting it into practice. Employee participation in decision making and problem solving in banking sector of Bangladesh has been recognized as a managerial tool for improving organizational performance and it increases employee satisfaction and an increase in productivity and profit. Increasing employee participation in decision making will impact optimistically on their growth and prospective for continued existence, and banks of Bangladesh should provide their employees such conveniences so that they feel comfortable to participate in decision making procedure and to give power motivational drive to them who wants to participate in decision making and problem solving. Participation of workers in decision-making process has resulted in successful value creation in banking sector of Bangladesh. This is actualized by way of allowing workers' input in developing the mission statement, establishing policies and procedures, pay determination, promotion, and determining perks. Employee participation in decision making has become a significant topic in human resource management (HRM), and is regarded as one of the chief ingredients of employee voice. Several studies have shown that allowing employees to participate in decision making leads to increase in motivation, job performance, and organizational benefit. However, many studies also have conflicting views on whether or not an increase in employee participation directly affects organizational performance.

\section{OBJECTIVES OF THE STUDY:}

The main objective of the study is to investigate the importance of employee participation and involvement in decision making and problem solving in the banking sector of Bangladesh. The specific objectives of the study are:

- To reveal the perception of employees regarding participative decision-making.

- To determine the causes of poor participation in decision making.

- To find out some benefits of employee participation in decision making.

- To explore the consequences of low employee involvement in decision making.

- To pick out some pitfalls of participation of employees in decision making.

- To explain the relationship between participative decision making and organizational Commitment.

- To provide some recommendations so that employee participation can bring fruitful results in the banking sector.

\section{LITERATURE REVIEW:}

Participation is the mental and emotional involvement of people in group situations that encourages them to contribute to group goals and share responsibility for them. There are three important ideas regarding participation in decision making-involvement, contribution and responsibility. Firstly, participation means meaningful involvement - rather than mere muscular activity. A second concept in participation is that it motivates people to contribute. They are empowered to release their own resources and creativity to achieve the objectives of the organization. Participation especially improves motivation by helping employees understand their paths towards goals. Thirdly, participation encourages people to accept responsibility for their group activities. Participation is social processes by which people become self involved in an organization and want to see it work successfully (Newstrom \& Davis, 2004). Sometimes employees' participation is matter psychological ownership among organizational members and has been implemented via the participation of employees in information processing, decision-making and/or problem solving. (Kearney, 1997). 
Decision-making is the process of identifying and selecting a course of action to solve a particular problem (Stone and Freeman (1984)'. So decision-making means the selection of a course of action among alternatives (Weihrich and Koontz (1993). But decision making in organizations has been described as a process of behavior with the economic model at one extreme and the social model at the other extreme (Kimberly and Rotman, 1987). This description implies that only irrational decision making accords human values precedence over economic values. Leaders must find some middle ground between these extremes for it is evident that neither set of values can be ignored. It is obvious that a whole company of skilled and capable problem solvers will have a distinct competitive advantage over an organization that only a few key distributors and an array of drones. (Apostolou, 2002).

Participative decision-making is the process by which employers allow or encourage employees to share or participate in organizational decision-making (Probst, 2005). The format of participative decision making might be formal or informal (Cotton et.al 1988). The degree of participation may vary from different perspective of Participative Management stages. It is one of the way by which an organization can make decisions. The leader or manager must think of the best possible style that will allow the organization to achieve the best results. Employees must have a sense of belonging to an organization to achieve the target of organization more effectively and efficiently. Decision-making is the process of identifying and selecting a course of action to solve a particular problem (Stone and Freeman (1984).

Research shows that Participation has statistically significant effects on performance and motivation (Wagner, 1994). If the employees are allowed to participate in decision making, they will feel that they are valued in the enterprise. They also provide necessary suggestions and guidelines to the organization for attaining its goal. As a result, development and necessary changes occur fruitfully in (1) setting goals, (2) making decisions, (3) solving problems and (4) designing and implementing organizational changes (Gilbraith et.el. 1993). This participative process enhances the capacity of employees in problem solving and increase the commitment to the organization's success. The underlying logic is that involving workers in decisions increasing their autonomy and control over their work which can be made them more motivated and more committed to the organization, more productive and more satisfied with their jobs (Ford and Fottler, 1995).

In case of employee participation, it ensures that every employee is regarded as a unique human being not just a cog in a machine and each employee is involved in helping the organization meet its goals. Allowing employees to participate in decision making leads to increase in motivation, job performance, and organizational growth (Gollan and Wilkinson, 2007; Kim, McDuffie and Pil, 2010; Bhuiyan, 2010; and Brown 1982). However, there are also have some conflicting views on whether or not an increase in employee participation directly affects organizational performance. Some critics, such as Sashkin (1976) views that participation is not only effective, but that its use by management is an ethical imperative. Locke and Schweiger (2001) believe that worker participation is merely a managerial technique that can be used effectively in certain situations. For example, In Nigeria, the institutionalization of worker participation within the nation's industrial relations system was championed by several scholars such as Adewumi, (1997), Fashoyin, (1992) and Imaga, (1994) who suggested that worker participation in managerial decision making will reduce industrial conflict, raise workers' productivity, ensure rapid grievance procedure and motivate workers. So Participation allows employees to exert some influence over their work 
and the conditions under which they work (Heller, Pusic, trauss and Wilpert, 1998) or alternatively which influence on decision making that is shared between hierarchical superiors and their subordinates (Wagner and Gooding, 1987).

There was a contention given by the McGregor (1960) that workers participation involves creating opportunity under suitable condition for people to influence the decisions that affect them. It is a special case of delegation in which the subordinate gains control, and has greater freedom of choice with respect to bridging the communication gap between the management and workers. This serves to create a sense of belonging among the workers, as well as a conducive environment in which the worker will voluntarily contribute to management efforts.

Employee participation in decision-making can be classified in terms of three properties (Locke and Schweiger, 1997). These are formal-informal, direct-indirect, and amount of influence. Formal participation has a system of rules to be followed, while informal participation can be casual like a conversation with a supervisor. Direct participation involves immediate personal involvement, while indirect participation involves some sort of employee representation. On the other hand, Cotton, Vollrath, Froggatt, Lengnick- Hall, and Jennings (1988) have classified the types of employee participation in decision making into six different combinations such as participation in work decisions, consultative participation, short-term participation, informal participation, employee ownership, and representative participation. But Levine and Tyson (1990) made different between consultative and substantive forms of participation. He thinks that in consultative forms, workers provide information or advice, but management retains the right to make decisions, while in substantive participatory system, workers have greater autonomous control over methods and pace of work.

Research findings of Khattak, Igbal and Bashir, (2012) also indicated that employee involvement and participation at work has significant positive effect on job satisfaction, leading to improved organizational performance.Chartered Institute of Personnel and Development (CIPD, 2001) provided the opinion that employee participation is 'a range of processes that designed to engage the support, understanding and optimum contribution of all employees in an organization and their commitment to its objectives'. Theorists and researchers such as McGregor (1957) and Hertzberg (1966) have strengthened this evidence that a wide variety of benefits may accrue to an organization that systematically develops and consciously encourages the participative style of management that is involving employees in decision-making. Higher degree of employee involvement does influence organizational effectiveness; some of which includes lower absenteeism, (Marks et al, 1986), enhanced work attitudes (steel and Lloyd, 1988), higher individual work performance (Bush and Spangler, 1990), lower employee turnover and increased returns on equity (Vandenberg et at, 1999), and improved organizational learning culture (Thompson, 2002).It also leads to increased product or service quality, greater innovation, stronger employee motivation, lower costs but a higher speed of production, and lower employee absenteeism and turnover (Lawler, 1996).Through this, productivity and efficiency would be greatly improved and some amount of strain and stress associated with working in some organizations would be removed.

Although there are some criticisms whether the participative decision making is effective or not but lot of studies concluded that to increase workers' commitment and humanize the workplace, with the intention of improving firms' performance and good citizenship 
behavior, managers need to permit a high degree of employee involvement in decision making (Kuye and Sulaimon, 2011; Ravenswood, 2011; Thornton, 2009; and Barringer and Bleudorn, 1999).

An empowered human resource that is employees will be able to respond more quickly to changes, improvements, new customer requirements as they begin to act independently in pursuit of their expectations and within the boundaries of their authority. An organization may have well-written policies concerning participation, and top management may even believe it is being practiced, but these policies and beliefs are meaningless until the individual perceives them as something important to his or her presence in the organization (Vandenberg et al., 1999).

People argued that something about management looks so easy that we all think we could succeed where others fail. But management is really not easy. They must be good at strategy, persuasion, and negotiation. Vision, fortitude, passion, intelligence, ethical standards, courage and tenacity are also being rigorous. (Teal, 1996). This study would make an attempt to remove the confusion whether the participative management in the banking sector is effective or not. It was provided opinion from the survey of employees in the banking sector of Bangladesh.

\section{METHODOLOGY OF THE STUDY:}

It is an exploratory research and it relies on secondary data such as reviewing available literature and/or data, or qualitative approaches such as informal discussions with consumers, employees, management or competitors, and more formal approaches through in-depth interviews, focus groups, projective methods, case studies or pilot studies.

\subsection{Sources of Data:}

Secondary information for this research was mainly through various publications collected from the internet, textbooks, journals, reports prepared by various universities. It has been scrutinized to assess its suitability, reliability, adequacy and accuracy. Primary data was collected through questionnaire. Questionnaires were also distributed to other categories of staff being managers, officers and clerks of the organization across branches to get a holistic view and understanding of the staff on involvement in decision making in the organization.

\subsection{Sample Size determination:}

There are near about 66 different branch of different banks exist in Dhaka city. So the population size is 66 . To get a statistically correct sample size from these 66 we have assumed confidence level $95 \%$ \& confidence interval $5 \%$.

\begin{tabular}{ll}
\hline \multicolumn{2}{c}{ Sample Size } \\
\hline Branch in Dhaka city & 66 \\
Confidence level & $90 \%$ \\
Confidence interval & $5 \%$ \\
Population size & 66 \\
\hline So sample size & 57 \\
\hline \multicolumn{2}{c}{ Source: http://www.raosoft.com/samplesize.html }
\end{tabular}

Finally sample size is 57. It is developed from www.raosoft.com. It is a good size that has a good tradeoff between time \& cost. These 57 Branches are needed to be selected from 66 Branches. In case of 
branch selection random sampling method was followed and interview was taken from the executive of each bank regarding employee involvement in decision making and problem solving. No personal judgment was made in selecting bank. The branches are those that were generated by software named random number generator.

\subsection{Sample design}

* Target Population: population of the study was limited to the executives of the different banks in different branch of Dhaka city.

* Sample frame: Managers, officers.

- Sample Size: The sample size of 57 was arrived at taking into consideration the extent of variability in the population, time constraints and framework within which the study was to be completed.

* Sample Area: All the branches of different banks within Dhaka city.

* Sampling unit: Individuals

\subsection{The study instrument- Tools used}

For this study, a structured questionnaire was used to collect primary data. The questionnaire was designed in such a way that would reduce the total error in the data collection process. The questionnaire was based on the funnel technique which started with the general questions and moved to specific ones so that respondents' biases could be reduced. All the questions were designed with a view to finding out what the employee truly think about the participation of decision making and problem solving in banking sector of Bangladesh. Statistical tool such as SPSS software were used to analyse the data. Beside SPSS software table, chart, graph were also used to conduct the study.

\subsection{Survey technique used/Sample selection:}

Non probability sampling (convenience sampling) technique has been used to collect data. This was purely convenience as this was the only feasible technique given resources, time and other variables. The respondents chosen were on a non random basis. Whoever was willing and was vicinity, participated in the survey.

\subsection{Data analysis}

The data was counted manually and then this data was entered into the SPSS software. This has many advantages. As paper questionnaire is used, the responses had to be taken manually one by one. This also helped to find out the biases and contradictions, which had to be eliminated in order to get a fair result.

\subsection{SOCIO-ECONOMIC PROFILE OF THE RESPONDENTS:}

\begin{tabular}{|l|l|l|}
\hline Gender & Frequency & Percentage(\%) \\
\hline Male & 33 & 58 \\
\hline Female & 24 & 42 \\
\hline Total & 57 & 100 \\
\hline
\end{tabular}

Table 2: Gender of respondents

*Source: field Survey

The table- 2 depicts the gender of the respondents which shows that $58 \%$ and $42 \%$ of respondents of male and female respectively answered the questionnaires distributed.

\begin{tabular}{|c|c|c|}
\hline Age & Frequency & Percentage $(\%)$ \\
\hline $20-29$ & 19 & 33 \\
\hline $30-39$ & 23 & 40 \\
\hline $40-49$ & 12 & 21 \\
\hline $50-59$ & 03 & 06 \\
\hline $60-69$ & 0 & 0 \\
\hline
\end{tabular}


In table-3 explained that 30-39 year group constituted $40 \%$ of respondents and was the highest number of respondents followed by 20-29 years with 33\% and then the 40-49 year group which made up $21 \%$ of the respondents. The lowest number of respondents was within the 50-59 year group which constituted 6\%. From the pattern that emerged, it can be said that majority of employees are young adults.

\begin{tabular}{|l|l|l|}
\hline No. of years & Frequency & Percentage (\%) \\
\hline $1-5$ & 36 & 63 \\
\hline $6-10$ & 11 & 19 \\
\hline $11-15$ & 03 & 05 \\
\hline $16-20$ & 04 & 07 \\
\hline $21-25$ & 02 & 04 \\
\hline $26-30$ & 01 & 02 \\
\hline \multicolumn{2}{|c|}{ Table 4: Year of Service } \\
* Source: Field survey
\end{tabular}

In table-4, Length of services of respondents was provided. According to respondents, their length of stay in the organization ranged from a minimum of 1 year to a maximum of 30 years. Thirty-six respondents making up $63 \%$ of the total has been in the service of the organization between 1-5 years. From Table 3 above, majority of respondents fell between the 1-10 years range forming a total of $82 \%$. The rest of respondents fall in the category of 11-30 years. The longest serving respondent fell in the 26-30 years category.

\begin{tabular}{|c|c|c|}
\hline Position & Frequency & Percentage (\%) \\
\hline Manager & 13 & 23 \\
\hline Officer & 32 & 56 \\
\hline Clark & 12 & 21 \\
\hline Total & 57 & 100 \\
\hline \multicolumn{3}{|c|}{ Table 6: Position of Respondents } \\
*Source: Field survey
\end{tabular}

The table- 6 of socio-demographic pattern of respondents is the position of respondents. Its indicates that, $23 \%$ of respondents were managers. However, majority of respondents fell in the officer grade making up 56\% with clerks making up the $21 \%$ to make a total of $100 \%$.

\begin{tabular}{|c|c|c|}
\hline Response & Frequency & Percentage (\%) \\
\hline Yes & 32 & 56 \\
\hline No & 15 & 26 \\
\hline No. response & 10 & 18 \\
\hline Total & 57 & 100 \\
\hline \multicolumn{2}{|c|}{ Table 7: Involvement of employee in decision making } \\
*Sources: field survey
\end{tabular}

Table -7 explained that the opinion of employees regarding involvement of decision making. $56 \%$ of respondents answered they were involved in decision making, $26 \%$ said they are not and $18 \%$ did not answer.

In the survey it was found that $96 \%$ of respondents are of the view that employee involvement would contribute effectively to the implementation of management decisions while $4 \%$ said it would not. This reflects that majority of the people in the organization under study are involved in decision-making in one way or the other.

It is a tool that promotes a win-win situation bringing about the realization that everyone is a stakeholder and therefore has to ensure that organizational goals are achieved for the benefit of all.

It came to light that the employees felt that their involvement in the decision-making process has also brought about a change in work attitudes and this experience motivates and boosts 
their morale which has awakened a sense of responsibility for assigned tasks and room for innovation and creativity.

\begin{tabular}{|c|c|c|}
\hline Response & Frequency & Percentage (\%) \\
\hline Yes & 47 & 82 \\
\hline No & 5 & 9 \\
\hline No. Response & 5 & 9 \\
\hline Total & 57 & 100 \\
\hline \multicolumn{2}{|c|}{ Table 8: Employee acceptance of decisions } \\
*Source: field survey
\end{tabular}

Table- 8 shows that $82 \%$ of respondents told that decisions would be accepted by all if employees are involved in the process, $9 \%$ do not believe it would and another $9 \%$ did not respond.

It can be also observed that, Lawler (1986) wrote that employee involvement is a stronger driver of financial performance than Total Quality Management or Re-engineering. This he said if well implemented, builds employees in as business partners so they know more and do more to make the organization successful, particularly in banking sector where the human component is important.

\begin{tabular}{|c|c|c|}
\hline Response & Frequency & Percentage (\%) \\
\hline Yes & 42 & 74 \\
\hline No & 10 & 14 \\
\hline No. Response & 7 & 12 \\
\hline Total & 57 & 100 \\
\hline
\end{tabular}

In Table-9, it has been found that $74 \%$ of respondents agree that participation in the decision-making process will lead to ownership and belongingness which will translate to acceptance and create the atmosphere for a well oiled implementation process. Even though $14 \%$ of respondents responded in the negative and $12 \%$ did not respond, it has been indicated from the data that majority are of the opinion that involvement in the decision-making process would yield positive results.

\begin{tabular}{|c|c|c|}
\hline Response & Frequency & Percentage (\%) \\
\hline Labour Unrest & 6 & 11 \\
\hline Job dissatisfaction & 12 & 21 \\
\hline Low productivity and tardiness & 11 & 19 \\
\hline Employee turnover and absenteeism & 3 & 5 \\
\hline All of the above & 24 & 42 \\
\hline None of the above & 1 & 2 \\
\hline Total & 57 & 100 \\
\hline
\end{tabular}

Table 10: Consequences of low employee involvement

Table-10, indicates that $11 \%$ of respondents said the impact of low employee involvement in decision-making would lead to industrial unrest, $21 \%$ said it would lead to job dissatisfaction, $19 \%$ said it would lead to low productivity and tardiness while 5\% said it would lead to employee turnover and absenteeism. $42 \%$ said it would lead to all of the above mentioned and $1 \%$ said it would lead to none of the above mentioned as shown in Table- 8 .

\section{FINDINGS:}

\section{Relationship between participative decision making and organizational commitment:}

\begin{tabular}{|c|c|c|c|}
\hline & Mean & Std. Deviation & $\mathrm{N}$ \\
\hline Org_Comit & 4.1228 & 1.01893 & 57 \\
\hline Participative_decis & 3.8772 & .96492 & 57 \\
\hline
\end{tabular}

Table 11: Descriptive Statistics

Table-11 explained the descriptive statistics about participative decision making and organizational commitment. Here the total respondent is 57 and mean and Standard deviation of organizational commitment is 4.1228 and 1.01893 as well as the mean and Standard deviation of participative 
decision making is 3.8772 and .96492 respectively.

\begin{tabular}{|cc|c|c|}
\hline & & Org_Comit & Participative_decis \\
\hline \multirow{2}{*}{ Pearson Correlation } & Org_Comit & 1.000 & .760 \\
& Participative_decis & .760 & 1.000 \\
Sig. (1-tailed) & Org_Comit &. & .000 \\
& Participative_decis & .000 &. \\
N & Org_Comit & 57 & 57 \\
& Participative_decis & 57 & 57 \\
\hline
\end{tabular}

Table-12: Calculation of Correlations between participative decision making and organizational commitment.

Table-12 displays Pearson correlation coefficient, significance values, and the number of cases with non-missing values. Pearson correlation coefficient assumes that the data are normally distributed and it is a measure of linear association between two variables. The values of the correlation coefficient range from -1 to 1 .

The sign of the correlation coefficient indicates the direction of the relationship (positive or negative). The absolute value of the correlation coefficient reveals the strong relationship between the two variables. In table-12, the correlation coefficient for participative decision making is .760 . Since .760 is highly positive and this indicates that participative decision making and organizational commitment are highly positively correlated, this means the higher the degree of participative decision, the higher the level of organizational commitment.

\section{REGRESSION ANALYSIS:}

\begin{tabular}{|c|c|c|c|}
\hline Model & Variables Entered & Variables Removed & Method \\
\hline 1 & Participative decision & $\begin{array}{llllllll} & \end{array}$ & $\begin{array}{l}\begin{array}{c}\text { Stepwise (Criteria: Probability-of-F-to-enter } \\
<=.050, \text { Probability-of-F-to-remove }>=.100) \text {. }\end{array}\end{array}$ \\
\hline
\end{tabular}

\begin{tabular}{|c|c|c|c|c|}
\hline Model & $\mathrm{R}$ & $\mathrm{R}$ Square & Adjusted R Square & Std. Error of the Estimate \\
\hline 1 & $.760^{\mathrm{a}}$ & .578 & .570 & .66789 \\
\hline
\end{tabular}

a. Predictors: (Constant), Participative decision making

\begin{tabular}{|cc|c|c|c|c|c|}
\hline & Model & Sum of Squares & Df & Mean Square & F & Sig. \\
\hline \multirow{4}{*}{1} & Regression & 33.606 & 1 & 33.606 & 75.337 & $.000 \mathrm{~b}$ \\
& Residual & 24.534 & 55 & .446 & & \\
\multicolumn{2}{|c|}{ Total } & 58.140 & 56 & & & \\
\hline
\end{tabular}

a. Dependent Variable: Organizational Commitment

b. Predictors: (Constant), Participative decision making

The value of $\mathrm{R}$ square is .570 (Table-14) shows the adequacy of the model in explaining the independent variable. The variables explain .578 percent of the variance in organizational commitment which is highly significant as indicated by the F-value (table-15). Finding shows that participative decision making has greater influence on organizational commitment.

\begin{tabular}{|c|c|c|c|c|c|c|c|}
\hline \multirow[t]{2}{*}{ Model } & \multicolumn{2}{|c|}{$\begin{array}{l}\text { Unstandardized } \\
\text { Coefficients }\end{array}$} & $\begin{array}{c}\text { Standardized } \\
\text { Coefficients }\end{array}$ & \multirow[t]{2}{*}{$\mathrm{t}$} & \multirow[t]{2}{*}{ Sig. } & \multicolumn{2}{|c|}{$\begin{array}{l}95.0 \% \text { Confidence In- } \\
\text { terval for B }\end{array}$} \\
\hline & B & Std. Error & Beta & & & $\begin{array}{l}\text { Lower } \\
\text { Bound }\end{array}$ & $\begin{array}{l}\text { Upper } \\
\text { Bound }\end{array}$ \\
\hline (Constant) & 1.010 & .369 & & 2.735 & .008 & .270 & $\begin{array}{r}1.750 \\
.988\end{array}$ \\
\hline Participative_decisio & .803 & .092 & .760 & 8.680 & .000 & .617 & \\
\hline
\end{tabular}


Table-16: shows that the beta value of participative decision making is .760 . This value suggests that participative decision making is significant variable that affect organizational commitment.

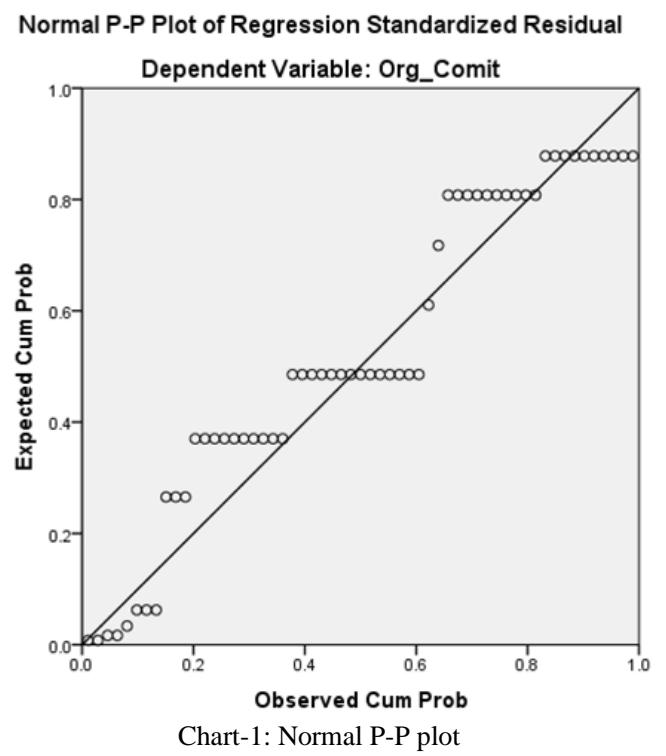

The above plot (Chart-1) represents a Normal P-P plot of the residuals. Notice that SPSS draws a 45-degree angle which represents the normal probability line. The dots, or boxes represent the actual residual. When look at this line, it make sure that the actual residuals fall on or close to the 45-degree line.

\section{ANALYSIS OF THE FINDINGS:}

From the survey an idea has been found that employees must be involved in the decision making process and also given the needed authority to be able to carry out their responsibilities to be effective and efficient. Majority of the employees were of the opinion that one critical and essential contributor to a positive workplace environment is marked by a sense of mutual respect and that is when employees are satisfied with their involvement in matters that affect their welfare in the office; especially when it is the place where they spend the best part of the day as well as their lives. To put it simply, people who are affected by a decision should have a voice in that decision-making process. Communication, from the research is one of the vital methods of any relationship and has been observed to lead to a cohesive and effective means of accomplishing Organizational goals. The initiative of 'owning' on the part of the employees would lead to a positive working environment as well as create and provide for nurturing and maintenance of such environment. It would encourage employees to identify and own the solutions to their problems.

Leadership is another method of enhancing employee empowerment as it emerged from the survey. It provides avenues to encourage and mentor employees who show leadership skills and abilities to sharpen and hone those skills for the benefit of all. The objective then is to create an environment where employees would not only have the fulfillment and benefit of their own strengths, but as members of a team, ensure that they become effective and contributing members of the organization.

By deliberating with employees on pertinent staff issues which are very touchy and emotional hinging on raw nerves bordering on the possibilities of strike actions and its attendant repercussions on the fortunes of the organization in an "we understand your plight but we need to discuss matters in a win-win scenario" will go a long way to avert such unhealthy and destructive actions.

From the above arguments it can be also said that, The employees felt that the consequences of low employee involvement are grave for any organization as it could lead to low productivity as a result of job dissatisfaction and even employee turnover though this may not be on the high side but some very good 
employees can be lost as a result of this. When this happens, an organization tends to spend a lot of money on recruitment and training. Some organizations become training grounds and recruitment centers for other organizations in the same industry in that they employ people, train them but because the staff do not have any sense of belongingness as a result of non participation in decision-making, they may leave or be poached by others. It does not help an organization to move forward in such circumstances.

From the study it is evident that participative decision making is significantly related with organizational commitment.

\section{Reasons for the non-participation of employees in decision making:}

The main reasons for non-participation of employees in decision making are given below:

1. Unwillingness of manager: Employees can not participating in decision making due to unwillingness of managers to involve their employees in decision making procedure. Managers hesitate to accept employees as valuable partners in decision making.

2. Centralization: Most of the managers in Bangladesh believe in centralize decision making authority. They think that decentralize decision making is the threat for their organization. Employees cannot participate in decision making because of banks centralized organizational structure. Moreover, most of the government banks follow centralized organizational structure.

3. Lack of knowledge of employees: Employees are not able to participate in decision making due to their lacking of knowledge in decision making and problem solving.

4. Political grouping: Political grouping is another reason for non-participative decision making in government banks but in my survey employees are agreeing with that there is no political grouping within their organization in terms of participation in decision making. Except this reasons, there are some other reasons for non- participation of employee in decision making. Employer finds some potential negative consequences if employees involve in decision making and problem solving such as:

- $\quad$ salary and training costs (developing new skills and responsibilities for lower-level participants results in increased salaries and additional training);

- $\quad$ support personnel (if the new program creates a new structure that needs support and management, support personnel must increase)

- $\quad$ Expectations for organizational change and personal growth and development opportunities(any program that talks about participation increases expectations for organizational change and personal growth, which, if it is limited or fails, results in dissatisfaction and cynicism)

- $\quad$ Resistance by middle management and/or staff support groups(if they are not positively affected by the program, they may resist it)

- Lost time (participation takes time and can slow decision-making because a number of people have to understand and accept the decision).

5. Managers hesitate to accept employees as valuable partners in decision making. From the view point of employees,

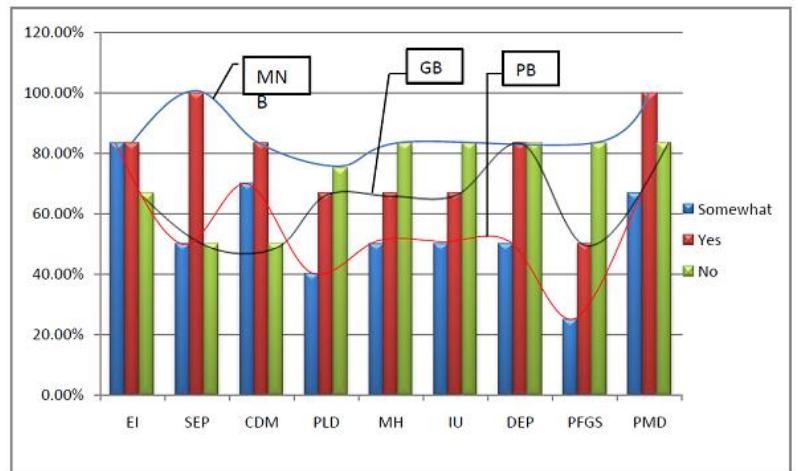

Graph-1: Comparison between Multinational Bank, Private Bank \& Government Bank in participative decision making: *EI=Employee Involvement PLD=Preference of Leaving Decision SEP=Significance of Employee Participation MH=Managerial Hesitation $\mathrm{CDM}=$ Comfortable about Decision Making IU =Inadequate Understanding DEP=Degree of Employee Participation PFGS=Pessimistic about Finding Good Solution PMD=Power Motivation Drive MNB=Multi National Bank

$\mathrm{GB}=$ Government Bank PB=Private Bank 
According to the graph-1: It has been found that multinational bank involve their employee in decision making more rather than other two because they believe that participation of employee in decision making includes more new ideas. On the other hand employee participation of government bank is lower due to various political influences. And nowadays private banks are increasing employee participation because the changed their mind set.

\section{Organizational Benefits of employees involvement in decision making:}

- Commitment of employees towards organizational will be increased if they involve in decision making.

- Overall productivity of an organization like banking will be increased through employee participation in decision making.

- Holistic performance of banking will be improved if the employees involve in decision making.

- Job satisfaction among employees increased via employee participation in decision making and problem solving.

- By the advent of participative decision making, better communication will take place between management and employees in the organization for future success of the organization.

- Turnover of the employees will be decreased as employees in the banking sector are satisfied by participating in decision making and problem solving.

- Conflicts and grievances of employees can be reduced through effective participation of employees in decision making and problem solving (better communication and improvement in union-management relationship reduces the number of grievances);

- $\quad$ Staff skills will be enhanced (problem-solving as well as technical skills are developed)

- Morale of employees will be enhanced if they involve in decision making.

\section{RECOMMENDATIONS}

All the banks in Bangladesh should ensure the importance of employee participation in decision making and problem solving. In our country government banks are not encouraging employee participation as they are following centralized organization system and most of their decisions are made by political influences. But they should not practice such kinds of activities. Many multinational banks are operating their activities in our country and they believe in employee participation and as well as practicing this thought. Our private banks' managements are changing their mind day by day and providing their employees power motivational drive to make decisions. So it is important for top management to share decision-making power in order to allow at least all employees regardless their hierarchical levels to influence decisions made at the workplace. Government oriented banks in Bangladesh has to realize that employee participation in decision making is amongst the most important elements which may improve the management of Banking sector. In other words, all banks should establish a participative management strategy founded on legislation or regulation which offers employees full rights to be involved in the decision-making process.

\section{CONCLUSION}

Management of a banking sector in Bangladesh can benefit immensely by adopting appropriate measures, and by reducing poor participation of the employees in decision making. The aim of the study was to map out the degree of employee participation in the decision-making procedure in the banking sector of Bangladesh and to identify whether employees desire to participate in decision-making and the importance of employee participation in decision making and problem solving in banking sector of Bangladesh. Findings of this result revealed that employee participation has significant impact on organizational performance. It can therefore be concluded that the importance of employee 
participation cannot be underestimated because it motivates employee to be committed to the organization. Participation especially improves motivation by helping employees understand their paths towards goals. And it encourages people to accept responsibility for their group activities.

\section{References}

Apostolou, A. (January 2002) INNOREGIO: Dissemination of innovation and knowledge management techniques. D. of Production Engineering \& Management, Technical University of Crete .Accessed 18.02.09.

Adewumi, F. (1993). "Industrial Relations Economic Development and Democracy": A Preliminary Note, E.F. Osuji Challenges Facing Industrial Relation In Nigeria in the Context of Emerging NewEconomic and Political order (Department of Adult Education University of Ibadan), PP. 59-82.

Barringer, B. R., \& Bluedorn, A. C., (1999). "The Relationship between Corporate Entrepreneurship and Strategic Management,” Strategic Management Journal. 20(50), 421 - 444.

Bhuiyan, M.H (2010). Employee Participation in Decision Making in RMG sector of Bangladesh: Correlation with Motivation and Performance. Journal of Business and Technology (Dhaka) 5(2), 122-132.

Brown, M. C (1982). Administrative succession and organizational performance: The succession effect, Administrative Science Quarterly 27, 1-16.

Cotton, J. L.,Vollrath, D. A., Froggatt, K. L., Lengnick-Hall, M. L and Jennings, Kenneth R. (1988):Employee participation: Diverse forms and different outcomes. In: Academy of Management Review, 13, S. 8-22.

Deninson, D. R. (1990). Corporate Culture and Organizational Effectiveness. New York: John Wiley \& Sons.

Ford C.R. and Myron D. F. (1995), "Empowerment: A Matter of Degree", Academy of

Management Executive, 9 (August): 21-31.

Fashoyin, T. (1992). Industrial Relations and African Development. New Delhi: South Asian Publishing Ltd.

Gilbrith, J.R., Edward e Lawler III and Associates (1993), "Organization for the Future: The New Logic for Managing Complex Organizations”, (San Francisco: Jossey- Bass), Chapter 6\&7.

.Gollan, P. J., \& Wilkinson, A. (2007). Contemporary developments in information and consultation. The International Journal of Human Resource Management, 18(7), 1133-1144.

Heller, F., Pusic, E., Strauss, G. and Wilpert, B. (1998). Organisational Participation: Myth and Reality, Oxford: Oxford University Press.

Imaga, E.U. (1994). Industrial Democracy in the Third World: A study of Nigeria and

India, New Delhi South Asian Publishers.

Kearney, W. (1997): A Proven Receipt for Success: The Seven Elements of World Class Manufacturing. National Productivity Review. Vol.16. No.4.

Kanter, R. M. (1982). Dilemmas of Managing Participation. Organizational Dynamics 10(Summer).

Khattak, M.A., Igbal. N and Bashir, F.(2012). Employee Involvement And Participation At Work: A Case Study Of OTCL After Privatization. International Journal of Academic Research in Business and Social Sciences. 2(6), 469-476.

Kim, J., MacDuffie, J. P., \& Pil, F. K. (2010). Employee voice and organizational

performance: Team versus representative influence. Human Relations, 63(3), 371-394.

Kuye, O. L and Suilaman A. A. (2011). Employee involvement in decision making and firms performance in the manufacturing sector in Nigeria. Serbian journal of management. 6(1), 1-15.

Levine, D. and Tyson, L. (1990). "Participation, productivity and the firm's Environment.” In A. Blinder ed.Paying for Productivity: A Look at the Evidence, Washington D.C:Brooklings Institute.

Locke, E.A., and Schweiger, D.M. (1997) Participation in Decision-making: One More Look. Research in Organizational Behaviour, 1: 265-339.

Lawler III., E. E. (1996). From the Ground Up: Six Principles for Building the New Logic Corporation. San Francisco: Jossey-Bass Publishers.

McGregor, D. (1960). The Human Side of Enterprise. New York: McGraw-Hill.

Newstrom J.W. and Davis Keith (2004), Organizational Behavior, Human Behavior at Work (11th Edition), Tata Mcgraw- Hill Co. Ltd. New Delhi, pp.187-200.

Newstrom and Davis (2004). In Bhuiyan, M.H (2010). Employee Participation in Decision Making in RMG sector of Bangladesh: Correlation with Motivation and Performance. Journal of Business and Technology (Dhaka) 5(2), 122-132. 
Ravenswood .K (2011). Productivity, Participation and Employee wellbeing in the Residential Aged Care sector.A PhD Thesis of Auckland University of Technology.

Stone, J. A. and Freeman, R.E. (1989). Management, Prentice Hall, Englewood Cliff, N.J.

Sashkin, M. (1976) Changing toward participative management approaches: A model and methods. Academy of Management Review. 75-86.

Thompson M.A (2002). An Exploratory Investigation of Learning Culture Theory and Employee Participation in Decision Making. Human Resource Development Quarterly. Vol. 13 No.3.

Thornton, R .C (2009). The impact of employee participation on the job satisfaction of blue- collar workers. A B.Sc. Thesis of the Colorado College.

Vanderberg R. J., Richardson H.A. and Eastman L.J. (1999). The Impact of High Involvement Work Processes on Organizational Effectiveness: A Second-Order Latent Variable Approach. Group and Organization Management, (24), 3.

Wagner, J. A., \& Gooding, R. Z. (1987) Effects of societal trends on participation research.Administrative Science Quarterly, 32: 241-262. 